\title{
The Construction and Structure Reliability of Jam Gadang: The Heritage of West Sumatra
}

\author{
Khadavi $^{1 \cdot}$ Yulcherlina ${ }^{2}$
}

\begin{abstract}
The Big Ben (Jam Gadang) is a tower building of 28.295 meters height positioned as the landmark and the heritage of both Bukittinggi city and West Sumatra province. It was built in 1926 by architects Yazin and Sutan Gigi Ameh as the gift from the Queen of the Netherlands to the controleur (secretary of Bukittinggi City). Major perception of the people that Jam Gadang was build by using masonry for the entire building. Following massive earthquakes in 2007 the Indonesian Heritage Trust in cooperation with the Shared Heritage Program of the Netherlands initiate full investigation of the tower. The activity was aimed at gathering data of the structure and analyzes the reliability of the current structure of the building. The result of such activities found that the construction of Jam Gadang consist of reinforced concrete with the compressive strength $\geq 25 \mathrm{Mpa}$ on average, the foundation consists of full stone with the prism shape until $-1,800 \mathrm{~mm}$. The column have a dimension with variation of $800 \mathrm{~mm} \times 800 \mathrm{~mm}$ at the first floor and $400 \mathrm{~mm} \times 400 \mathrm{~mm}$ at the top floor of the tower, with $18 \mathrm{~mm}$ longitudinal and $10 \mathrm{~mm}$ shear reinforcement, the beam and plate have the composite structure of steel beam H 105.90.10.25. The modeling and analysis of the structural reliability of Jam Gadang tower for earthquake load based on the Indonesian Code SNI-03-28472002, with maximum lateral deformation of $\left(\delta_{\max }\right) 63.00 \mathrm{~mm}$ which is smaller than lateral deformation limit of $83.70 \mathrm{~mm}$.
\end{abstract}

Keywords: heritage, jam gadang, reliability, and structure

\section{Introduction}

Jam Gadang is the landmark of both Bukittinggi city and west sumatera province that was built in the year of 1926 by architects Yazin and Sutan Gigi Ameh. The first ground breaking was done by oldest son of Rook Maker who was six years old. The Jam Gadang was a gift from the Queen of the Netherlands to the controleur (secretary of Bukittinggi City). In the era of ducth collonial, the roof top ornament was found a statue of rooster, and it was changed to pagoda form in the era of Japan collonial. Furthermore, in Indonesian independent era it had been changed to become ornament of Minangkabau Traditional House.

A long with the times and earthquake occured in Sumatera island, the Jam Gadang should be normally threatened as an object of cultural heritage for its preservation. However, the big earthquake with high richter scale happened in few years ago, it did not have any significant effect on Jam Gadang construction exception for crack. Therefore, this situation has been being an interesting debates for academicians. Previously, many people either in Bukittinggi or elsewhere hypothesized the building of the Jam Gadang was a tower construction that were all composed of masonry including Los Saudara Building (see Fig 1). The logical reasons behind this contention was most of Netherlands building made of masonry. However, the earthquake dated March 6th, 2007 with moment magnitude Mw 6.3 has significant

\footnotetext{
${ }^{1}$ Civil Engineering Departement Faculty of Civil Engineering and Planning Bung Hatta University e-mail: qhad_17@yahoo.com

${ }^{2}$ Civil Engineering Departement Faculty of Civil Engineering and Planning Bung Hatta University e-mail: yulcherlina@bunghatta.ac.id
} 
different impact on building of Jam Gadang and Los Saudagar. In other words, the earthquake collapsed the building of Los Saudagar and gave a little crack for Jam Gadang.

Based on previous some earthquakes with relative high magnitude including potential seismic events in the future, it is needed efforts to save the objects of cultural heritage for preservation which is one them called Jam Gadang. Indonesian Heritage Trust through the grant Shared Heritage Program of the Netherlands conducted data recording overall construction of Jam Gadang and studied the reliability of its structure. The results would be useful as a basis in the process of rehabilitation and reconstruction in order to meet the rules and principles of preservation for cultural heritage.

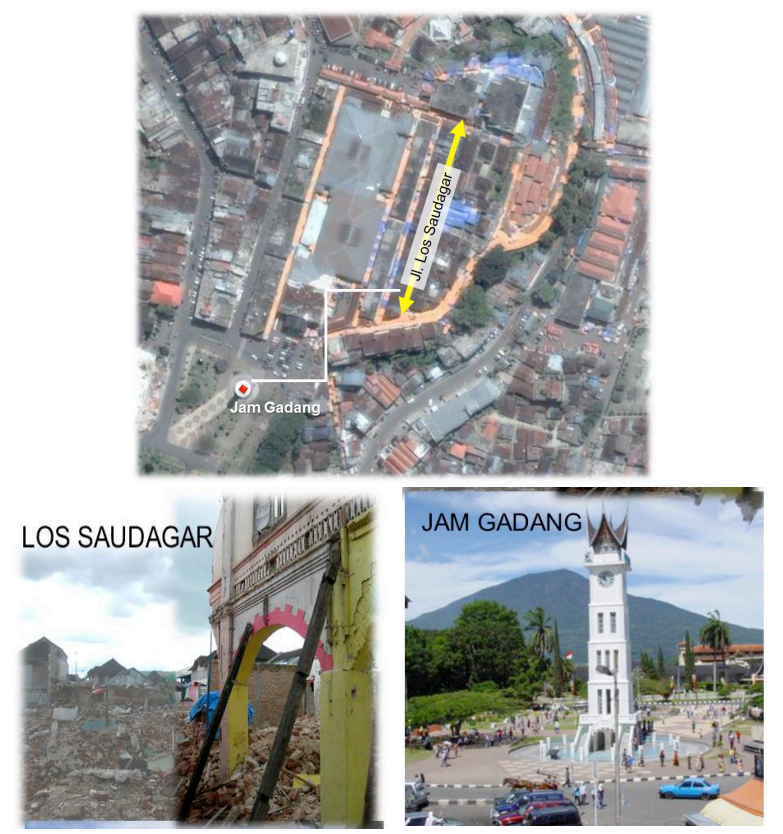

Figure 1 Position of Jam Gadang dan Los Sudagar in Post Earthquake 2007

\section{Basics of Planning, Preservation Heritage Cities and Cultural Heritage Objects}

The conservation activities were not only focused on the protection of single buildings or artifacts / monuments of Jam Gadang but Indonesian Heritage Preservation Agency also developed policies based protection area (area-based conservation). In the second phase of the conservation activities, The functional characteristics and economical utilization of protected area becomes aspects which is considered in the assessment of cultural significance beside the visual aspect, architectural, aesthetic and historical values (Tiesdell et al, 996., and Larkham, 1996)

Conservation activities consist of cultural heritage and natural heritage that has particular significance. As an activity of protection, preservation and conservation have a foundation of a dynamic concept, which always follow and respond to the times development through a number of stages and processes. Preservation of heritage cities including cultural heritage objects is not as freezing the life and culture, but it is an attempt to understand and absorb the wisdom, values and spirit of the past to be developed as a preparation for the future. Structuring heritage city and the cultural heritage objects is an effort to continually integrate and orient heritage in city development. The utilization of cultural heritage objects should be able to bring the people's welfare and improvement of quality of life, strengthening the 
physical, economic, social and cultural simultaneously. Furthermore, structuring and preservation of heritage city and the cultural heritage objects are complete and comprehensive efforts to managing heritage cities so that people loved the heritage and cultural life and develop a vibrant economy based on local wisdom and rules of preservation.

City Charter Heritage Preservation of Indonesia stated that the instrument arrangement and preservation of heritage cities are as follows:

1. Institutional and Governance Heritage Cities

2. Inventory and Documentation Heritage

3. Information, Education and Promotion of Heritage Cities

4. Economic Heritage Cities

5. Disaster Risk Management for Heritage Cities

6. Development of Life Culture Society

7. Heritage Cities Space Planning and Infrastructure

8. Layout Design of Heritage Cities

Therefore, the inventory process and construction documentation as well as disaster risk management at the Jam Gadang is part of running the instruments. Process and protection of the Jam Gadang area implemented by BPPI aims to provide decision-making in an effort to prepare the planning document of rehabilitation for the Jam Gadang (development of plant) in accordance with the process of building and environmental preservation (see Fig.2)

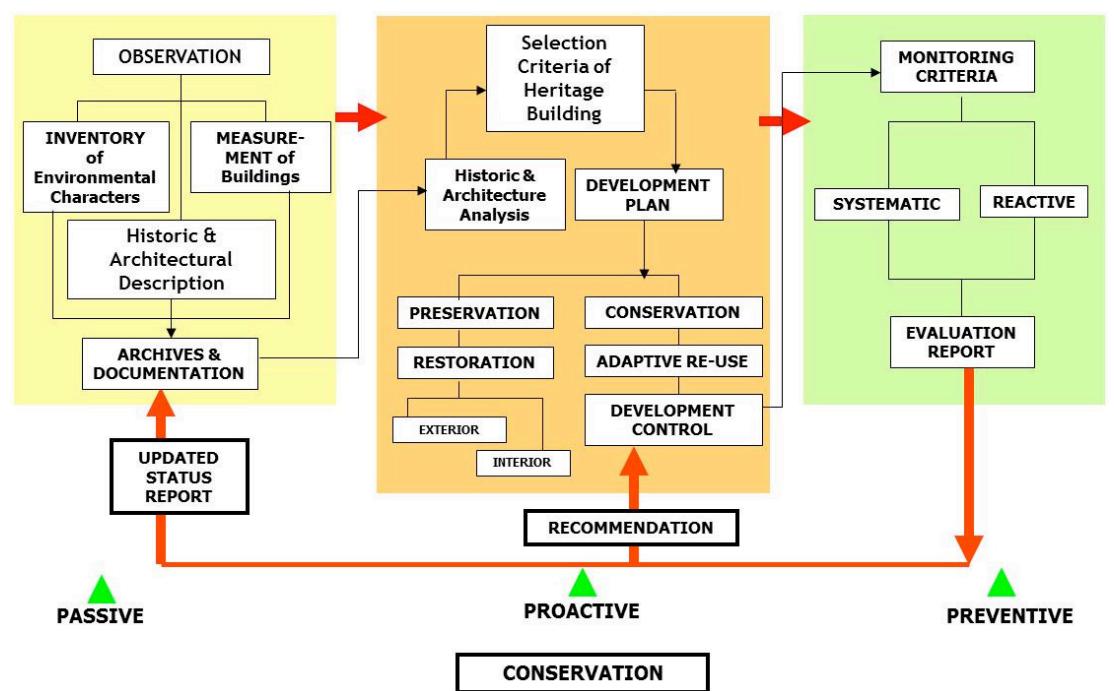

Figure 2 Scheme of Building Process and Environmental Preservation

\section{Reliability Analysis of Structures}

The analysis and evaluation of the structure reliability is to obtain justification for Jam Gadang save. In analyzing the structural model, it is defined based on the results of the investigation of the Jam Gadang construction data recording. The imposition of gravity load is defined by Indonesian Loading Codes for Home and Building (SNI-03-1727-1989), while earthquake loading is defined by Indonesia Seismic Resistance Stuctural Building Codes (SNI-03-1726-2002). The seismic analysis was conducted using static equivalent for irregular structural configurations, structure tall no more than 10 or 40 meter level with a combination of dead load (D), live load (L) and seismic load (E) as follows: 
(1) $\quad 1.4 \mathrm{D}$

(2) $\quad 1.2 \mathrm{D}+1.6 \mathrm{~L}$

(3) $\quad 1.2 \mathrm{D}+1.0 \mathrm{~L} \pm 1.6 \mathrm{WL}$

(4) $\quad 0.9 \mathrm{D} \pm 1.6 \mathrm{WL}$

(5) $\quad 1.2 \mathrm{D}+1.0 \mathrm{~L} \pm 1.0 \mathrm{Ex} \pm 0.3 \mathrm{Ey}$

(6) $1.2 \mathrm{D}+1.0 \mathrm{~L} \pm 0.3 \mathrm{Ex} \pm 1.0 \mathrm{Ey}$

(7) $0.9 \mathrm{D} \pm 1.0 \mathrm{Ex} \pm 0.3 \mathrm{Ey}$

(8) $\quad 0.9 \mathrm{D} \pm 0.3 \mathrm{Ex} \pm 1.0 \mathrm{Ey}$

Based on the SNI-03-1726-2002, buildings categories have primacy I, the earthquake reduction factor $R$, and time of fundamental natural shakes $T_{1}$, then a large force equivalent static base shear V nominal happens on the ground level can be calculated according to this equation;

$$
V=\frac{C_{1} \cdot I}{R} W_{t}
$$

$\mathrm{C}_{1}$ is earthquake response factor obtained from earthquake spectral response spectrum. For a natural period $\mathrm{T} 1$, different seismic zone and $\mathrm{W}_{\mathrm{t}}$ as the total weight of the building. The natural period $T_{1}$ limited, depends on coefficient structure type $(\zeta) . H$ is structural total height, and force static equivalent nominal $\mathrm{Fi}$ as equation follows;

$$
F_{i}=\frac{W_{i} \cdot z_{i}}{\sum_{j=1}^{n} W_{j} \cdot z_{j}} . V
$$

$\mathrm{Wi}$ is the heavy floor level-i, zi is the height of the floor level-i, while $\mathrm{n}$ is the highest floor level. If the ratio of height to the size of the building structure diagram in the direction of an earthquake is equal to or more than 3 , then the top floor will be given earthquake loads at $0.1 \mathrm{~V}$, and other $0.9 \mathrm{~V}$ will be distributed to the below floors. After obtaining the deviation of each level through the calculation of technical engineering, the time structure of natural shakes controlled again by using the formula of Rayleigh :

$$
T_{1}=6.3 \sqrt{\frac{\sum_{i=1}^{n} W_{i} \cdot d_{i}^{2}}{g \cdot \sum_{i=1}^{n} F_{i} \cdot d_{i}}}
$$

$d_{i}$ is defection on the floor-i, due to load of $F_{i}$, expressed, and $g$ is the gravitational acceleration of $9810 \mathrm{~mm} / \mathrm{s}^{2}$. The result of this calculation should not exceed $20 \%$ of the count in the equation of $\mathrm{T}_{1}<\xi \mathrm{H}^{3 / 4}$

Results of analysis on the structural reliability of Jam Gadang will be confirmed on the theory of the full elastic structure (see Fig 3), the condition of the structure is on the verge of collapse is achieved in line with the first thaw in the structure $(\delta \mathrm{m}=\delta \mathrm{y})$ 


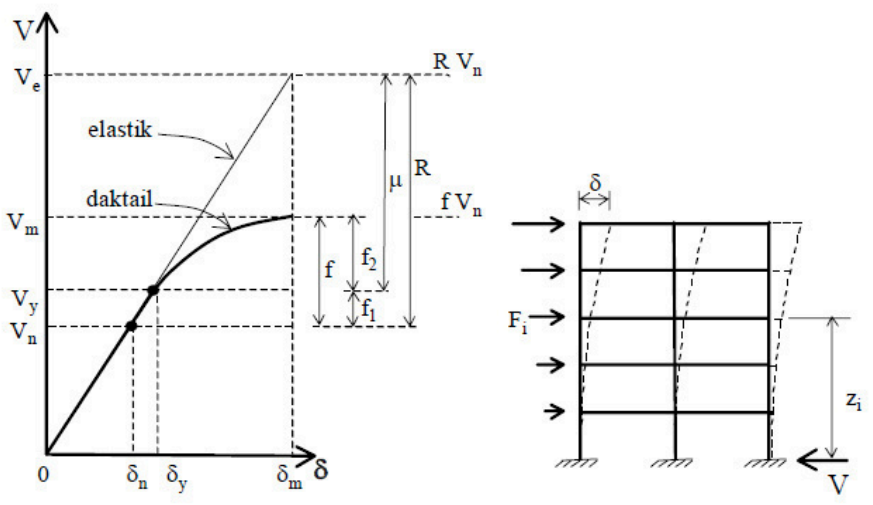

Figure 3 Load-Displacement Structure Building Diagram

\section{Construction and Structure of Documentations Result}

There are two methods used in examining of building structures, namely qualitative sampling and quantitative consideration of the Jam Gadang. The qualitative was done through observation and visual field examination, as well as retrieval of documentation, while quantitative methods conducted in the form of configuration measurement and construction elements, investigation of current condition and damage of building, as well as testing the structural components for evaluation. The collecting of structural elements in the form of measurement; dimensions, strength of concrete with a hammer test, homogeneity test with concrete by ultrasonic pulse velocity (UPV), the configuration reinforcement with profometer, and chipping sample that including foundation identification. The results of measurement and testing can be seen follows:

A. The results of measurement identification building consisting of 5 floors with a total height of $28.295 \mathrm{~m}$ (see Fig 4)

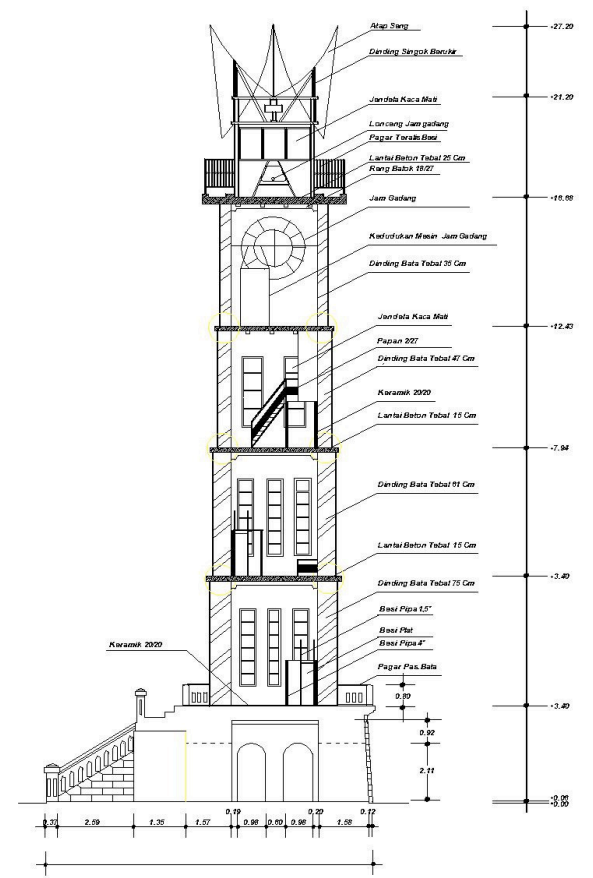

Figure 4 Measurement Result of The Building 


\section{B. Damage Recording}

The dominant damage in the masonry wall, this model is most common in the wall panel charger which direction diagonal joint-burdened will experience the press, otherwise the diagonal direction perpendicular to experience the attraction, the tension force caused a diagonal panel crack (see Fig 5).

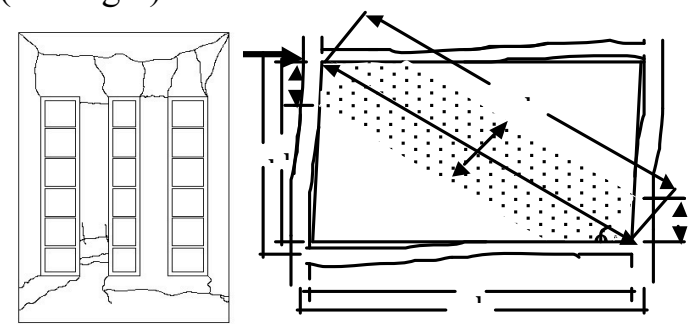

Figure 5 Strut Diagonal Crack of Masonry

C. Recording the data foundation by the Heritage Preservation Board was obtained through excavation. It was found that a foundation stone arranged pair prism to a depth of $-1650 \mathrm{~mm}$ with uniform soil structure in the form of clay. Interestingly, it was also proven that there are no signs of damage or settlement in the foundation (see Fig 6)

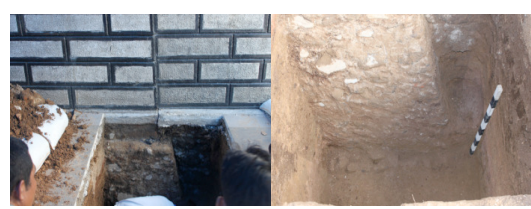

Figure 6 Foundation Observations

D. Identifications of the construction and the upper structure; It was found that the Jam Gadang structure has reinforced concrete open frame, beam and plate is composite structure, construction of masonry walls consisted of masonry, except for the clock placement namely a wall of reinforced concrete. The following is the results of identification and testing for each component:

(a). Column

The column is a reinforced concrete structure with varied dimensions (see Fig 7) Jam Gadang has four reinforced concrete columns on each floor which is located on the four corners of the building that its vertical geometry growing smaller to the top, but the columns is aligned. The damage that occurs only in the form cracked cover width $0.5-0.8 \mathrm{~mm}$ at outer side in the column direction on first floor only.

(b). Beam and Slab

The beams and floor slabs on the building of the Jam Gadang has a composite structure. Based on the results of examination found no new damage to the floor plate and beams, while the dimentions of the slab is as follows (see Table 1). 

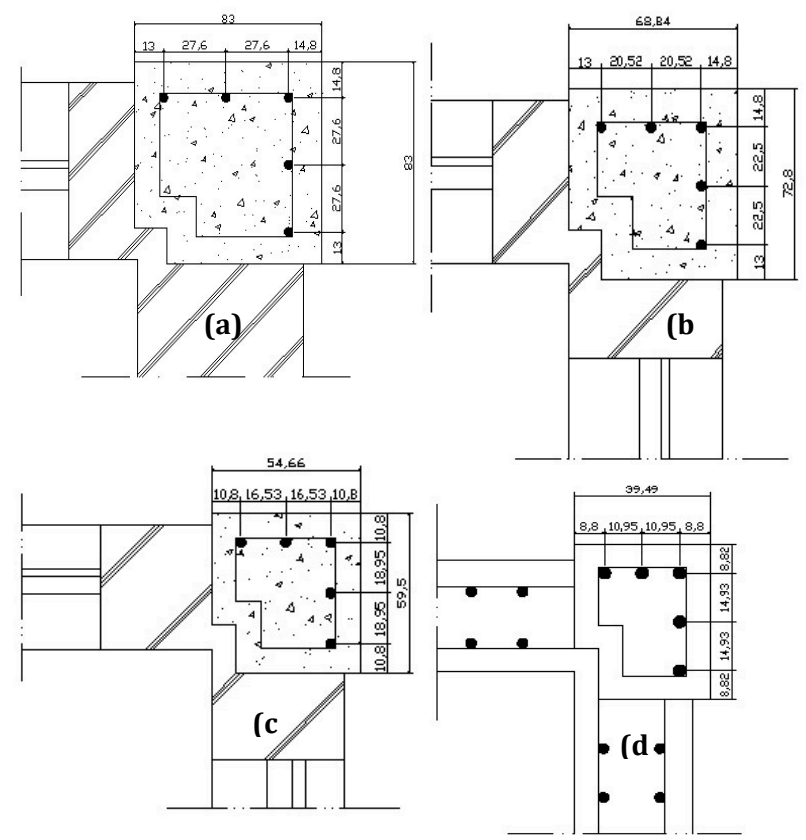

Figure 7 Results of Indentification on Column (a) $2^{\text {nd }}$ Story (b) ${ }^{3 \text { rd }}$ Story $(c)^{4 \text { th }}$ Story $(d)^{5 \text { th }}$ Story

Table 1 Dimensional of Slab

\begin{tabular}{|c|c|c|}
\hline Slab & $\begin{array}{c}\text { Width } \times \text { Length } \\
(\mathrm{mm})\end{array}$ & Thickness $(\mathrm{mm})$ \\
\hline $1^{\text {st }}$ & $2960 \times 2960$ & 175 \\
\hline $2^{\text {nd }}$ & $2960 \times 2960$ & 175 \\
\hline $3^{\text {th }}$ & $2960 \times 2960$ & 175 \\
\hline $4^{\text {th }}$ & $2960 \times 2960$ & 175 \\
\hline $5^{\text {th }}$ & $2960 \times 2960$ & 250 \\
\hline
\end{tabular}

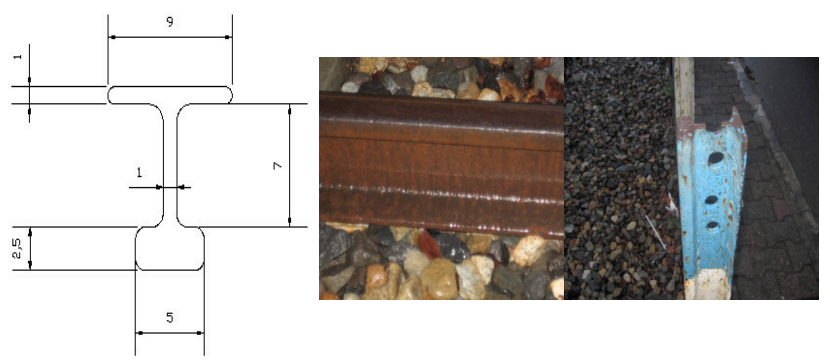

Figure 8 H-Beam of Composite Beams and Slab

(c).Wall

The walls of the Jam Gadang is built from a masonry (see Fig 9) with varying thickness, respectively $640 \mathrm{~mm}, 600 \mathrm{~mm}, 460 \mathrm{~mm}$ and $340 \mathrm{~mm}$. Dimensions of brick is an average size of $180 \times 130 \times 50 \mathrm{~mm}$. 
The walls of Jam Gadang are not designed as a structure, wall as a partition. It is not found anchorage to the walls of the columns, but a special wall at $5^{\text {th }}$ story is true planned as part of the construction to bear clock (see Fig 10)

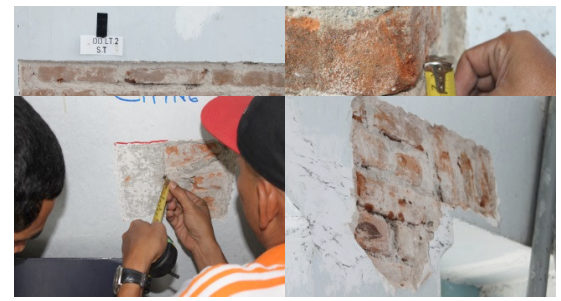

Figure 9 Masonry Wall

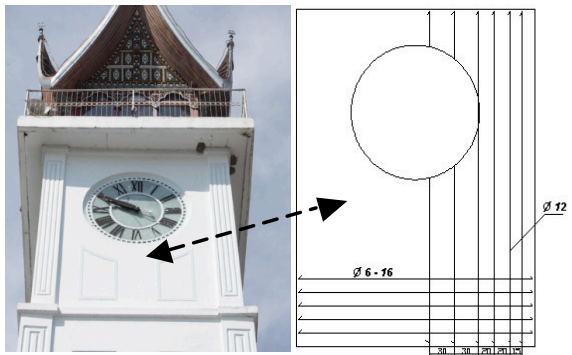

Figure 10 Reinforcement Configuration in Top Wall

Table 2 Results of Hammer and UPV Test

\begin{tabular}{|l|c|c|c|c|}
\hline Structural & Story & \multicolumn{3}{|c|}{ Test Result } \\
\cline { 3 - 5 } Component & & $\begin{array}{c}\text { Hammer } \\
(\mathrm{MPa})\end{array}$ & Ultrasonic Velocity \\
\cline { 3 - 5 } & & & Homogenitas & $\begin{array}{c}\text { Crack } \\
(\mathrm{mm})\end{array}$ \\
\hline Column & 2nd & 46.517 & Good & 56 \\
& 3th & 33.150 & Good & \\
& 4th & 37.500 & Good & \\
& 5th & 33.200 & Good & \\
\hline Beam & 2nd & 32.500 & & \\
& 3th & 32.500 & & \\
& 4th & 39.100 & & \\
& 5th & 43.200 & & \\
\hline Plat & 1st & 51.517 & Very Good & \\
& 2nd & 30.667 & Very Good & \\
& 3th & 50.617 & Very Good & \\
& 4th & 43.150 & Very Good & \\
& 5th & 46.800 & Very Good & \\
\hline
\end{tabular}

E. The Results of Concrete Testing

Hammer test has done at columns, beams and slabs to identify the compressive strength of the concrete surface. UPV test also done on the componens to determine the homogeneity/uniformity of concrete and measure into the crack. These test results show concrete has good quality and was not found a significant crack, the test results are provided in Table 2.

\section{The Results of Modeling and Structure Analysis}

Based on the results of construction data recording, it is found the construction modeling (see Fig 11) and strutctural modeling of Jam Gadang (see Fig 12).

In this analysis, structure of Jam gadang is modelled as 3D whereas dimension and material properties are from previous data of recording results. The main building structure is 
analyzed with seismic load plan for erthquake map Indonesia zone 5. Data analysis: total wight (Wt) $410.65 \mathrm{kN}$, natural period (T) 0.495 , basic earthquake coefficient (C) 0.9 , and structural primacy factor (I) 1.6, it is acquired seismic force of $695.69 \mathrm{kN}$, whreas the maxsimum deflection that occures $63.00 \mathrm{~mm}$ or it is smaller than deflection limit of $83.7 \mathrm{~mm}$.

The capacity of column provided is still meet the requirement of strength and stiffness, availability of reinforcement extents (minimum reinforcement ratio) on the seismic load plan. This findings can be seen from charts of column interaction (see Fig 13)

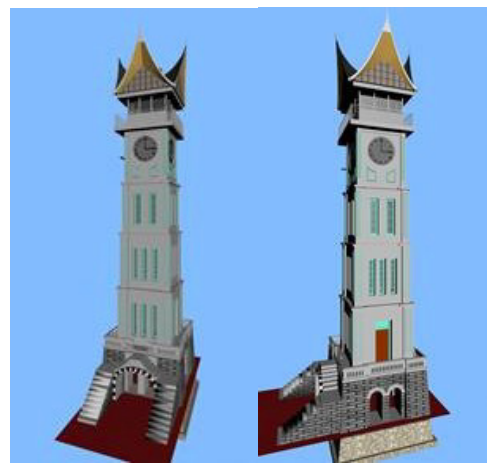

Figure 11 Construction Modelling

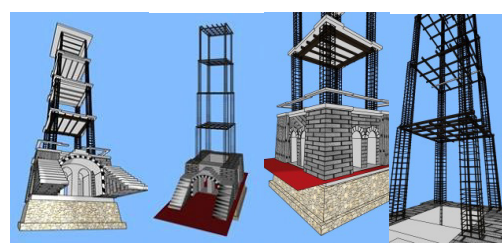

Figure 12 Structural Modelling

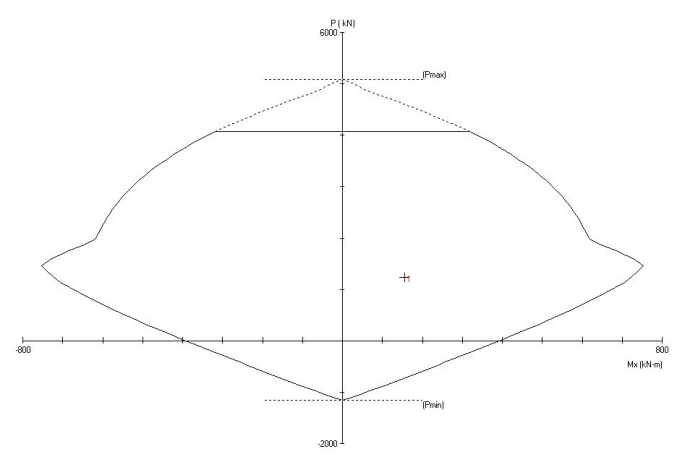

Figure 13 P-M Interaction Diagram $1^{\text {st }}$ Column

\section{Disscusions and Conclussions}

The efforts of construction data recording and structure of Jam Gadang have produced the current condition, whereas no damage found. In other words, the Jam Gadang is generallyin safety. Although, the wall of Jam Gadang only suffered demage on plaster, and there are no new cracks as consequnces of earthquake in March 2007 and Septermber 30th, 2009. The foundation with depth of $1690 \mathrm{~mm}$ arranged are found no demage. Furthermore, there is no signs of damage found on the ground floor. Therefore the column must consist of reinforced concrete structure that still has sufficient capacity. The analysis of structural reliability displays that the Jam Gadang is elastic on seismic load with a maximum deviation which accounted for $63.00 \mathrm{~mm}$. This finding is relatively caompred to 3D application laser scanner 
photogramettry that conducted by Indonesian Heritage Trust which is found the deflection is below 1 derajat.

Therefore, in the early stages of rehabilitation plan of Jam Gadang, it is not necessary yet to strengthen the structure. However, the efforts to reduce building load besides providing protection on architechtural elements in line with time of building, and restriction for the numbers of visiting guests.

In order to sustain preservation of Jam Gadang, it is need the future researh in the long run to confirm detailling upper structure (reinforced concrete) with under structure (foundation stone) as well as soil investigation. So, it will totally support decisions for preservation.

\section{Acknowledgment}

My special appreciations to Catrini P. Kubontubuh as Executive Director of Indonesia Heritage Trust (BPPI) and team, Eko Alvares and his team, Amrinsyah Nasution (ITB), and others.

\section{References}

Imran, I. (2010). Perencanaan Detailing Struktur Beton Bangunan Tinggi Sistem Ganda, Step by Step Calculation berdasarkan SNI 03-2847-2002. IMHERE B2C FTSL. ITB

Imran, I., Yuliari, E., \& Suhelda \& Kristianto, A. (2008). Aplicability Metoda Desain Kapasitas pada Perancangan Struktur Dinding Geser Beton Bertulang. In Seminar dan Pameran HAKI-Pengaruh Gempa dan Angin terhadap Struktur.

Laboratorium Teknologi Beton Universitas Bung Hatta. (2010). Laporan Pemeriksaan dan Investigasi Struktur Jam Gadang.

Mangkoesoebroto, S. P. (2007). Seismic Performance Chart for Simple Structures (No. 1). Research Report Series.

Mangkoesoebroto, S.P., Goto, T., \& Khadavi. (2003). Investigation of Full-Scale Confined Masonry in Reversed Cyclic. The Ninth East Asia-Pacific Conference on Structural Engineering and Construction.

Martokusumo, W., \& Zulkaidi, D. (2014). Heritage List. Some Notions on Area-based Conservation. Lesson Learned from Bandung. Proceeding on International Conference on Urban and Regional Planning, University Teknologi Malaysia, Skudai, Johor Bahru

Martokusumo, I. I. W. (2010). The Ex-Coal Mining City of Sawahlunto Revisited. Nakhara: Journal of Environmental Design and Planning, 6, 107-118.

Martokusumo, W. (2008). Urban Heritage And Modern Project, Critical Notions On Conservation And Heritage Management. A Brief Look At The Case Jakartae" s Kota Tua. Journal Of Southeast Asian Architecture, 11, 51-62.

Orbasli, A. (2008). Architectural conservation: principles and practice. Blackwell Science.

Purwono, R., Tavio., Imran, I., \& Raka I.G.P. (2007). Tata Cara Perhitungan Struktur Beton untuk Bangunan Gedung (SNI 03-2847-2006) dilengkapi Penjelasan, ITSPress, Surabaya, Indonesia.

Wallace, J. W., \& Orakcal, K. (2002). ACI 318-99 provisions for seismic design of structural walls. Structural Journal, 99(4), 499-508.

Yoshimura, K., Kikuchi, K., Kuroki, M., Nonaka, H., Croston, T., Coga, S., Kim, K.T., Itai, T., Matsumoto, Y., Ma, L. (2001). Experimental Study on Effects Reinforcing Details Seismic Perfomance of Masonry Wall. 26th Conference on Our World in Concrete and Structures Singapore

SNI-03-2847-2002. Tata Cara Perhitungan Struktur Beton untuk Bangunan Gedung.

SNI-03-1726-2002. Tata Cara Perencanaan Ketahanan Gempa untuk Bangunan Gedung.

SNI-03-1727-2001. Pedoman Perencanaan Pembebanan untuk Rumah dan Gedung.

SNI-03-4802-1998. Kriteria Keseragaman Kualitas Beton.

SNI-03-4430-1997. Metode Pengujian Kuat Tekan Elemen Struktur Beton Dengan Alat Palu Beton 